\title{
Response of proline accumulation in bread wheat (Triticum aestivum L.) under rainfed conditions
}

\author{
Mukhtar AHMED $^{\mathrm{a}, \uparrow}$, Fayyaz-ul-Hassan ${ }^{\mathrm{a}}$, Ghulam QADIR $^{\mathrm{a}}$, Farid Asif SHAHEen ${ }^{\mathrm{b}}$ and Muhammad Aqeel Aslam ${ }^{\mathrm{a}}$ \\ ${ }^{a}$ Department of Agronomy, PMAS Arid Agriculture University Rawalpindi-46300, Pakistan \\ ${ }^{b}$ Department of Entomology, PMAS Arid Agriculture University Rawalpindi-46300, Pakistan
}

\begin{abstract}
Drought and high temperature stress are the major limitation for the crop productions. Proline as osmoregulator in wheat plant under these stresses was studied through field experiments. The experimental design was randomized complete block with four factors i.e. the environment (2008-09 and 2009-10), sowing management (Planting windows PW's; PW1, PW2, PW3, PW4 and PW5), genotypes (Chakwal-50, Wafaq-2001 and GA-2002) and locations (Islamabad, Chakwal and Talagang) replicated four times. Proline contents measures at anthesis stage of wheat crop depicted significant differences in response to treatments and among locations maximum value recorded at Talagang $\left(39.13 \mu \mathrm{g} \mathrm{g}^{-1}\right)$ followed by Chakwal $\left(32.36 \mu \mathrm{g} \mathrm{g}^{-1}\right)$ and Islamabad $\left(24.55 \mu \mathrm{g} \mathrm{g}^{-1}\right)$. However among PW's maximum proline recorded for PW5 $\left(35.42 \mu \mathrm{g} \mathrm{g}^{-1}\right)$ due to exposure of crop to water and high temperature stresses as it was planted late. The inverse relationship of proline with physiological traits and grain yield was observed except for stomatal resistance where it remained positive. In conclusion proline accumulation improved the yield of wheat crop under water and temperature stress by regulating leaf water potential. Since, genotypes Chakwal-50 accumulated highest proline contents in present studies therefore; it needs to be considered for recommendation under stress conditions.
\end{abstract}

Key words: Anthesis, High temperature stress, Moisture stress, Proline, Wheat

\section{Introduction}

Dryland ecosystems depend upon rainfall therefore crop survival is significantly affected due to variability in rainfall as well as temperature. The establishment of crop under such climate has strong link with rainfall and evapotranspiration pattern (Hubbell, 2001). The arid and semi-arid regions account for approximately $30 \%$ of the world total area and are inhabited by approximately $20 \%$ of the total world population. The risk will be more severe in future because of decline in the mean annual rainfall (Dore, 2005). The occurrence of rainfall in future would decrease significantly while intensity may increase resulting fragile weather conditions (Easterling et al., 2000). Similarly, rise in temperature intensify drought by increased evapotranspiration (Hughes, 2003). The environmental stresses like high temperature and drought slow down crop growth and speed up accumulation of biochemical like proline. Under such severe environmental conditions plants adopt specific strategies to coup abiotic environmental stresses. These adaptation strategies include metabolic adjustments those result to accumulation of different organic compounds like proline, sugars and betaines. Similarly, physiobiochemical changes in plants enable them to survive under harsh environmental conditions. Stress responsive accumulators in plant body includes organic compounds like nitrogenous compounds which include quaternary ammonium compounds $\left(\mathrm{RN}^{+}\right)$, polyamines $\left(\mathrm{RNH}_{2}\right)$, proline and different other amino acids $\left(\mathrm{RNH}_{2} \mathrm{CHCOOH}\right)$. The second class includes hydroxyl compounds like sucrose,

Received; October 21, 2014.

Accepted; September 7, 2016.

'Corresponding Author: ahmadmukhtar@uaar.edu.pk

DOI: 10.2480/agrmet.D-14-00047 disaccharides and polyhydric alcohols.

Proline is the amino acid which accumulates in plants widely under environmental stresses. The action of proline in response to environment stresses includes osmotic adjustments, stabilizing sub cellular structures, destroying free radicals and buffering redox potential in the cell (Ashraf and Foolad, 2007). The increase of compatible osmolytes of low molecular weight enables plants to develop osmotic adjustment under stress conditions and proline is one of them. Proline does not interfere with normal biochemical reactions and maintain survival of crop under stress. Similarly, it is perfect osmoprotectant which can neutralize the effect of osmotic stress. Increased concentration of proline in plant parts has been reported under severe water stress and salinity (Aziz and Khan, 2001). The synthesis of proline in plant follows two routes from ornithine which involves transamination followed by cyclization and reduction of ornithine. In first route it changes to glutamate semialdehyde by ornithine aminotransferase. This glutamate semialdehyde could also be produced from glutamic acid by pyrroline 5-carboxylate synthetase.

The response of crop to abiotic stresses is complex mechanism which can take place at macro and microlevel. The macrolevel includes whole crop while microlevel is cellular level from which main hierarchy of reaction starts (Foolad and Lin, 2001). Therefore, plant growth is affected significantly due to complex interactions between stress factors and physiological, biochemical and molecular phenomena's going on in plant body in response to stresses (Zhu, 2002). The uses of economical and technological means are missing to aid crop production under abiotic stresses. The promising solution to this problem is to use such crops which have tolerance mechanism in response to environmental stresses which could help to feed the billions of peoples in the developed and under-developing countries. 
However, development of tolerant crops requires complete understanding of physiochemical mechanism going on in plant body in response to stresses. Therefore, to develop stress tolerant crops information regarding genes and genetic control at different phenological stages is required. The use of biotechnology in the development of stress tolerant crops have shown significant potential in last two decades at micro level that is molecular level (Rontein et al., 2002). The mechanism of stress tolerance varies from crop to crop and at different phenology (Foolad and Lin, 2001) but overall response of crop to abiotic stresses at microlevel is conserved (Zhu, 2002). However, abiotic stresses may trigger osmotic-oxidative stress, and denaturation of amino acids in crops which might lead to accumulation of solutes like proline and quickening of nascent oxygen hunting systems (Zhu, 2002).

The one degree rise in temperature in recent decades has hit wheat production in subcontinent, therefore, adaptation options needs to be considered for sustainable yield production. The production of compatible organic solutes (COS) to abiotic stresses is common defensive mechanism in crops. These COS have low molecular weight, non-toxic at high concentration and highly soluble by making hydrogen bonding. COS protect the crops/ plants from stress by making osmotic adjustment, detoxification of reactive nascent oxygen, maintain membrane integrity and stabilizing functional and other proteins (Bohnert and Jensen 1996). They also protect cells from dehydration, therefore the COS might be called as osmoprotectant. The COS includes quaternary ammonium compounds (glycine-betaines, alanine-betaine, proline-betaine, choline- $O$-sulfate, hydroxyl-proline-betaine, and pipecolate-betaine) proline, sucrose, polyols and trehalose. The production of COS as desirable traits in plants have been achieved by producing genetically engineered plants with little success. However, this can be achieved with more success by studying response of available genotypes under stress conditions and thereafter recommending them under stress conditions for sustainable yield production. Therefore, the prime objective of present study was to check the production of proline in response to high temperature and water stress for further recommendation of genotypes under different locations of rainfed agriculture.

\section{Materials and Methods}

\subsection{Study sites}

Field trials on wheat crop were performed during two wheat growing years (2008-09(Y1) and 2009-10(Y2)). The three study sites were Islamabad $\left(33^{\circ} 40^{\prime} \mathrm{N}, 73^{\circ} 10^{\prime} \mathrm{E}\right)$, Chakwal $\left(32^{\circ} 56^{\prime} \mathrm{N}\right.$, $\left.72^{\circ} 52^{\prime} \mathrm{E}\right)$, and Talagang $\left(32^{\circ} 55^{\prime} \mathrm{N}, 72^{\circ} 25^{\prime} \mathrm{E}\right)$. The Islamabad is located in the high rainfall zone and has dry sub-humid climate with $>1000 \mathrm{~mm}$ average annual rainfall and an average annual temperature of $21.3^{\circ} \mathrm{C}$. The semi-arid site Chakwal $(600 \mathrm{~mm}$ average annual rainfall) is situated in the medium rainfall zone, and has an average annual temperature of $22.4^{\circ} \mathrm{C}$. Talagang has an arid climate (290 $\mathrm{mm}$ average annual rainfall) and is located in the low rainfall zone. The average annual temperature is $23.7^{\circ} \mathrm{C}$ at Talagang. Rainfall during the wheat growing season (November to April) is highly variable, with the seasonal variability being greater than the annual. The abiotic factors, rainfall and temperature prevailed during crop growing period is represented in Figs. 1 and 2.

\subsection{Planting windows}

The five planting windows (PW's) were denoted as PW1 $\left(20^{\text {th }}\right.$ and $23^{\text {rd }}$ October at Islamabad while at Chakwal and Talagang $16^{\text {th }}$ and $22^{\text {nd }}$ October), PW2 (Sowing on $26^{\text {th }}$ October and $5^{\text {th }}$ November at Islamabad while at Chakwal and Talagang $25^{\text {th }}$ and $31^{\text {st }}$ October), PW3 (Sowing on $5^{\text {th }}$ and $19^{\text {th }}$ November at Islamabad while at Chakwal and Talagang $6^{\text {th }}$ and $14^{\text {th }}$ November), PW4 (Sowing on $19^{\text {th }}$ and $27^{\text {th }}$ November at Islamabad while at Chakwal and Talagang $15^{\text {th }}$ and $23^{\text {rd }}$ November) and PW5 (Sowing on $5^{\text {th }}$ and $10^{\text {th }}$ December at
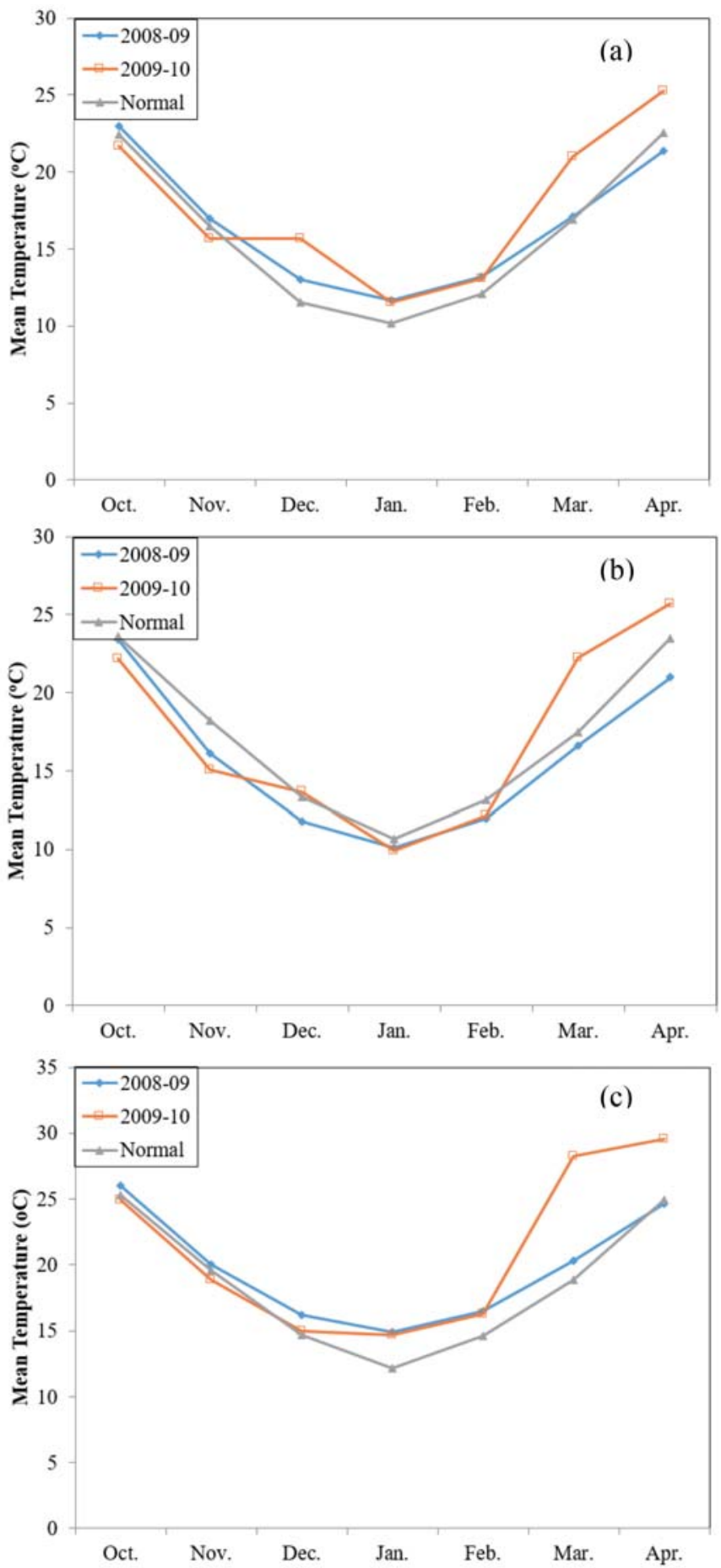

Fig. 1. Monthly distribution of temperature averages at Islamabad (a), Chakwal (b) and Talagng (c). 
Islamabad while at Chakwal and Talagang $4^{\text {th }}$ and $5^{\text {th }}$ December) during 2008-2009 (Normal Year) and 2009-2010 (Stress year) respectively.

\subsection{Plant material}

Three wheat genotypes Chakwal-50, Wafaq-2001 and GA2002 were used in the experiments. The plot size was $4.5 \times 10 \mathrm{~m}$ with the row to row distance of $30 \mathrm{~cm}$. The seed rate used was $50 \mathrm{~kg}$ per acre. The land was prepared using cultivator followed by mouldboard plough. Urea $(46 \%)$ at $100 \mathrm{~kg} \mathrm{ha}^{-1}$ was used in
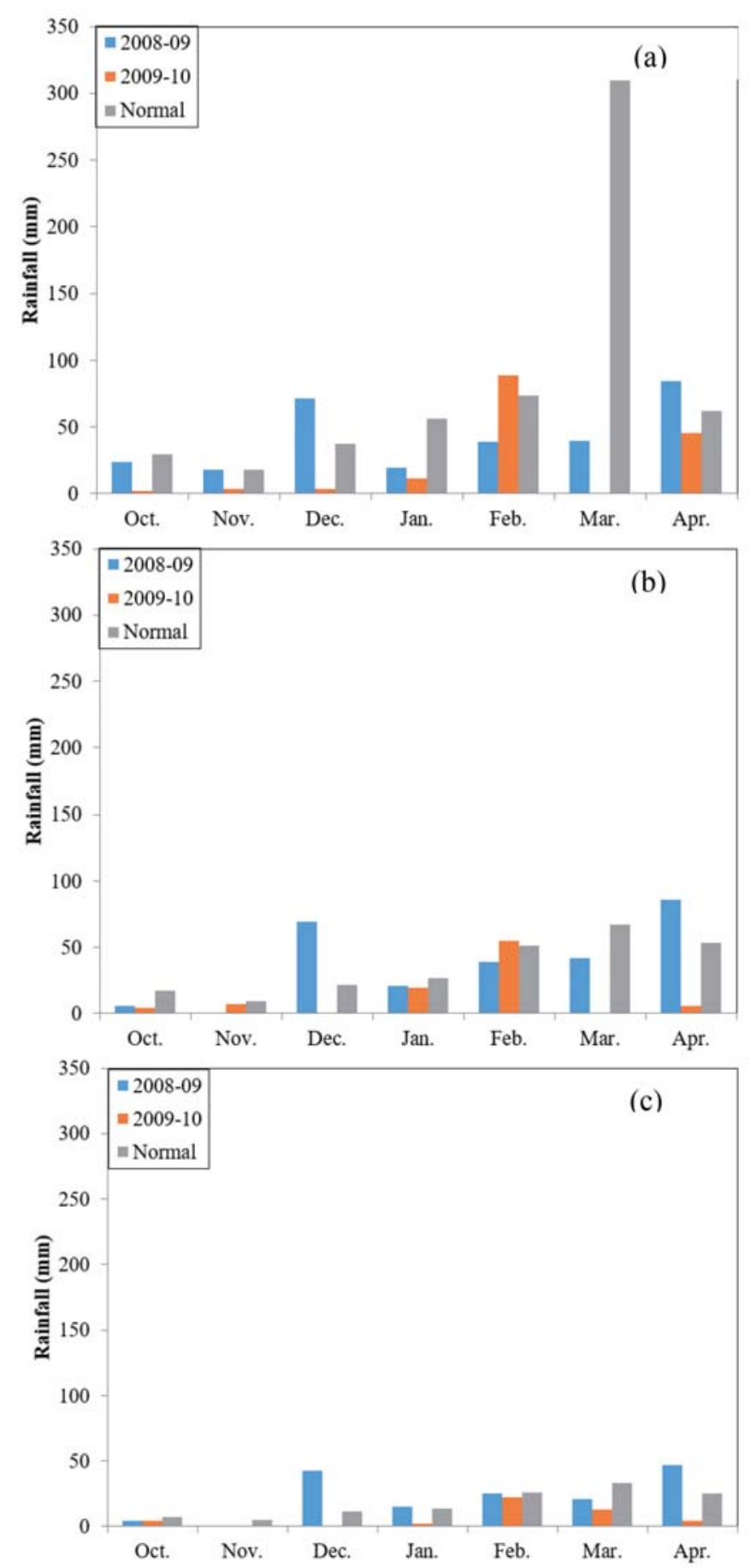

Fig. 2. Monthly distribution of rainfall at Islamabad (a), Chakwal (b) and Talagng (c). each plot as source of $\mathrm{N}$ applied at the time of sowing. P fertilizer at $75 \mathrm{~kg} \mathrm{ha}^{-1}$ was provided in the form of DAP. K was not applied as adequate soil- available $\mathrm{K}$ was in soil at three sites.

\subsection{Soil water potential and leaf water potential determination}

Soil water potential was determined using tensiometer at anthesis stage at the depth of $30 \mathrm{~cm}$. The ten flag leaves of plants from each treatment were used to determine leaf water potential $\left(\Psi_{\mathrm{W}}\right)$. The five measurements were made early in the morning between 09:00 and 11:00 by using Scho-lander type pressure chamber (ARIMAD-2, ELE-International).

\subsection{Proline content at anthesis}

Randomly ten flag leaf samples at anthesis stage of wheat were collected from three locations Islamabad, Chakwal and Talagang represented as Normal, moderate and high water stress areas respectively based upon long term climatic data. Meanwhile based upon long term temperature data, Islamabad was considered as optimum temperature area followed by Chakwal and Talagang where high temperature stress was observed. Similarly, leaves samples at anthesis were taken from five planting windows of three locations. The samples from each treatment i.e. years (200809 (Normal year) and 2009-10 (Stress year)), locations, planting windows, genotypes were homogenised in ten $\mathrm{ml}$ Sulphosalicyclic acid $\left(\mathrm{C}_{7} \mathrm{H}_{6} \mathrm{O}_{6} \mathrm{~S}, 3 \% \mathrm{w} / \mathrm{v}\right)$ solution at room temperature and stored at $4{ }^{\circ} \mathrm{C}$ for overnight. The supernatant obtained was added with glacial acetic acid and acid ninhydrin and reaction was conducted in a test tube for one hour at $100^{\circ} \mathrm{C}$ while reaction was terminated by putting test tube in ice bath. The $4 \mathrm{ml}$ of benzene derivative toluene was used to extract the sample in a test tube stirrer for 15-20 s. The extracted samples were analysed using UV-visible spectrophotometer at $520 \mathrm{~nm}$ (Thermo Electron, Model Bio Mate 3, Massachusetts, USA). The concentration of proline was determined by calibration curve and expressed as mg proline per gram fresh weight.

\subsection{Statistical analysis:}

The experiments were arranged as a randomized complete block design (RCBD) with four replications $(n=4)$. The treatments considered as factors were Years (2008-09 and 2009-10), Locations (Islamabad, Chakwal and Talgang), Planting windows (PW1, PW2, PW3, PW4 and PW5) and Genotypes (Chakwal-50, Wafaq-2001 and GA-2002). The analysis was conducted using STATGRAPHICS Centurion software (STATGRAPHICS for Windows seven version, USA) for analysis of variance and comparison of means. Moreover, Box-whisker plot was drawn to show response of proline concentrations in response to all treatments.

\section{Results}

\subsection{Climatic data description}

The rainfall during two growing years i.e. 2008-09 and 200910 at Islamabad (High rainfall zone) was 297 and $154 \mathrm{~mm}$ respectively compared to longterm seasonal average i.e. $586 \mathrm{~mm}$ (Fig. 2). However, seasonal (ONDJFMA) average temperature remained at 17 and $18^{\circ} \mathrm{C}$ during $2008-09$ and $2009-10$ respectively compared to longterm average i.e. $16^{\circ} \mathrm{C}$. The increased temperature recorded during 2009-10 in the month of March and April when 
crop was at grain filling stages might result to terminal heat stress (THS) (Fig. 1). The total seasonal rainfall at medium rainfall zone (Chakwal) remained at $263 \mathrm{~mm}$ during 2008-09 while $92 \mathrm{~mm}$ (65\% reduction) during 2009-10. The longterm average seasonal rainfall at this site was $246 \mathrm{~mm}$. Variability in temperature remained high during 2009-10 in the months of FMA (Fig. 1). At Talagang which was low rainfall zone the seasonal rainfall remained at 154 and $45 \mathrm{~mm}$ during 2008-09 and 2009-10 respectively compared to longterm average i.e. $121 \mathrm{~mm}$. Similarly, great variability in temperature was recorded during two years (2008-09 and 2009-10) particularly at flowering stage of crop. In general seasonal rainfall distribution differed from one environment to another and from one location to another (Figs. 1 and 2). The rainfall remained effective during 2008-09 but during 2009-10 limited rainfall resulted to stress conditions for crop (Fig. 2).

\subsection{Leaf water potential ( $\left.\Psi_{\mathbf{w}}\right)$}

Water and temperature stress under variable climatic conditions significantly reduced the leaf water potential. Among years the highest $\Psi_{\mathrm{W}}$ was during 2008-09 which reduced significantly during 2009-10 (Table 1). Similarly, $\Psi_{\mathrm{W}}$ remained significantly different among locations and planting windows. The highest $\Psi_{\mathrm{W}}$ remained under optimum conditions of Islamabad and PW2 compared to stress conditions at Talagang and PW5.

\subsection{Soil water potential}

Soil water potential was significantly different under all treatments. Among years the highest soil water potential remained during 2008-09 while it remained lowest during 2009-10. Soil water potential among genotypes remained highest in the field of Chakwal-50 compared to other genotypes. Soil water potential remained maximum at Islamabad compared to all other locations while among PW's significant different for soil water potential observed. The highest soil water potential recorded for PW2 followed by PW1 while it remained lowest in PW5 (Table 1).

\subsection{Proline Contents}

The results of proline contents across years revealed that it remained significantly different at $P<1 \%$ level (Table 1 ). Proline contents for two years (2008-09 and 2009-10) in wheat at anthesis combined over locations, genotypes and managements (Planting windows) revealed the maximum contents $(36.25 \mu \mathrm{g}$ $\left.\mathrm{g}^{-1}\right)$ during 2009-10 as compared during 2008-09 (27.90 $\left.\mu \mathrm{g} \mathrm{g}^{-1}\right)$ (Table 1). The proline under stress $(2009-10)$ was $23.39 \%$ greater than favourable environment (2008-09). However, under normal conditions (2008-09) the amount of proline at anthesis stage was significantly lower (Fig. 3) compared to stress conditions (2009-10). The box-whisker plot depicted deviation from mean higher during 2009-10 compared to normal conditions.

Proline contents for variable climatic locations of Pothwar (Islamabad, Chakwal and Talagang) depicted significant differences (Table 1 and Fig. 3). The maximum value of proline in leaf recorded at Talagang $\left(39.13 \mu \mathrm{g} \mathrm{g}^{-1}\right)$ followed by Chakwal $\left(32.36 \mu \mathrm{g} \mathrm{g}^{-1}\right)$ and Islamabad $\left(24.55 \mu \mathrm{g} \mathrm{g}^{-1}\right)$. The reduction in proline at Islamabad was $37.26 \%$ compared to highest value of proline which was recorded at Talagang. The main effect of genotypes showed significant variability for proline contents combined over three locations, five planting windows and two years (Table 1). The maximum proline contents $\left(33.61 \mu \mathrm{g} \mathrm{g}^{-1}\right)$ recorded in Chakwal-50 followed by Wafaq-2001 $\left(31.90 \mu \mathrm{g} \mathrm{g}^{-1}\right)$ and GA-2002 $\left(30.52 \mu \mathrm{g} \mathrm{g}^{-1}\right)$. Proline content at anthesis stage of wheat under variable environmental parameters provided in the form of planting windows (PW) depicted significant difference (Fig. 3 and Table 1). The highest proline was recorded for PW5 $\left(35.42 \mu \mathrm{g} \mathrm{g}^{-1}\right)$ followed by PW4 (33.82 $\left.\mu \mathrm{g} \mathrm{g}^{-1}\right)$, PW3 $\left(32.10 \mu \mathrm{g} \mathrm{g}^{-1}\right)$, PW1 $\left(30.74 \mu \mathrm{g} \mathrm{g}^{-1}\right)$ and lowest value noted for PW2 $\left(27.97 \mu \mathrm{g} \mathrm{g}^{-1}\right)$.

The interactive effect of Y x L, Y x PW, L x PW, Y x G, L x $\mathrm{G}$ and $\mathrm{PW} \times \mathrm{G}$ on proline contents depicted highly significant effect while Y x L x PW, Y x L x G, Y x PW x G, L x PW x G and $Y \times L \times P W \times G$ interactions remained non-significant for proline contents in flag leaf of wheat (Table 1). The interactive

Table 1. Response of proline contents, 1000 grain weight and grain yield of wheat under different treatments.

\begin{tabular}{cccccc}
\hline Treatments & $\begin{array}{c}\Psi_{\mathrm{W}} \\
(-\mathrm{MPa})\end{array}$ & $\begin{array}{c}\text { Soil water } \\
\text { potential } \\
(-\mathrm{MPa})\end{array}$ & $\begin{array}{c}\text { Proline } \\
\text { Content } \\
\left(\mu \mathrm{g} \mathrm{g}^{-1}\right)\end{array}$ & $\begin{array}{c}1000 \\
\text { grain } \\
\text { weight }(\mathrm{g})\end{array}$ & $\begin{array}{c}\text { Grain } \\
\left(\mathrm{t} \mathrm{ha}^{-1}\right)\end{array}$ \\
\hline
\end{tabular}

\section{Years (Y)}

Y1 (2008-09) $-0.61^{\mathrm{a}} \quad-0.1^{\mathrm{a}} \quad 27.77^{\mathrm{b}} \quad 39.16^{\mathrm{a}} \quad 2.81$

Y2 (2009-10) $-0.92^{\mathrm{b}} \quad-1.2^{\mathrm{b}} \quad 36.25^{\mathrm{a}} \quad 26.82^{\mathrm{b}} \quad 1.65^{\mathrm{b}}$

\section{Locations (L)}

\begin{tabular}{|c|c|c|c|c|c|}
\hline Islamabad & $-0.6^{\mathrm{a}}$ & $-0.11^{\mathrm{a}}$ & $24.55^{\mathrm{c}}$ & $40.10^{\mathrm{a}}$ & $3.19^{\mathrm{a}}$ \\
\hline Chakwal & $-0.85^{\mathrm{b}}$ & $-0.75^{\mathrm{b}}$ & $32.36^{\mathrm{b}}$ & $32.40^{\mathrm{ab}}$ & $1.89^{\mathrm{b}}$ \\
\hline Talgang & $-0.98^{\mathrm{c}}$ & $-1.1^{\mathrm{c}}$ & $39.13^{\mathrm{a}}$ & $26.47^{\mathrm{b}}$ & $1.62^{\mathrm{c}}$ \\
\hline \multicolumn{6}{|c|}{ Genotypes (G) } \\
\hline Chakwal-50 & $-0.64^{\mathrm{a}}$ & $-0.22^{\mathrm{a}}$ & $33.61^{\mathrm{a}}$ & $41.00^{\mathrm{a}}$ & $3.58^{\mathrm{a}}$ \\
\hline Wafaq-2001 & $-0.73^{b}$ & $-0.32^{\mathrm{b}}$ & $31.90^{\mathrm{b}}$ & $31.05^{\mathrm{b}}$ & $2.06^{\mathrm{c}}$ \\
\hline GA-2002 & $-0.86^{\mathrm{c}}$ & $-0.55^{\mathrm{c}}$ & $30.52^{\mathrm{c}}$ & $37.93^{c}$ & $2.55^{\mathrm{b}}$ \\
\hline \multicolumn{6}{|c|}{ Managements (PW) } \\
\hline PW1 & $-0.75^{\mathrm{b}}$ & $-0.2^{\mathrm{b}}$ & $30.74^{\mathrm{d}}$ & $34.72^{\mathrm{c}}$ & $2.52^{\mathrm{b}}$ \\
\hline PW2 & $-0.62^{\mathrm{a}}$ & $-0.12^{\mathrm{a}}$ & $27.97^{\mathrm{e}}$ & $37.22^{\mathrm{a}}$ & $3.12^{\mathrm{a}}$ \\
\hline PW3 & $-0.89^{\mathrm{c}}$ & $-0.95^{\mathrm{c}}$ & $32.10^{\mathrm{c}}$ & $35.09^{\mathrm{b}}$ & $2.05^{\mathrm{c}}$ \\
\hline PW4 & $-0.97^{\mathrm{d}}$ & $-1.12^{\mathrm{d}}$ & $33.82^{\mathrm{b}}$ & $32.88^{\mathrm{d}}$ & $1.84^{\mathrm{d}}$ \\
\hline PW5 & $-1.2^{\mathrm{e}}$ & $-1.33^{\mathrm{e}}$ & $35.42^{\mathrm{a}}$ & $29.05^{\mathrm{e}}$ & $1.62^{\mathrm{e}}$ \\
\hline \multicolumn{6}{|l|}{ Interactions } \\
\hline YxL & $* * *$ & $* * *$ & $* * *$ & $* * *$ & $* * *$ \\
\hline YxPW & $* * *$ & $* * *$ & $* * *$ & $* * *$ & $* * *$ \\
\hline LxPW & NS & NS & $* * *$ & NS & NS \\
\hline YxLxPW & $* * *$ & $* * *$ & NS & $* *$ & $* * *$ \\
\hline YxG & $* * *$ & $* * *$ & $* * *$ & NS & $* * *$ \\
\hline LxG & $* * *$ & $* * *$ & $* * *$ & NS & $* * *$ \\
\hline YxLxG & NS & NS & NS & NS & NS \\
\hline PWxG & $* * *$ & $* * *$ & $* * *$ & NS & $* * *$ \\
\hline YxPWxG & $* * *$ & $* * *$ & NS & $* *$ & $* * *$ \\
\hline LxPWxG & NS & NS & NS & NS & NS \\
\hline YxLxPWxG & NS & NS & NS & NS & NS \\
\hline
\end{tabular}

Where $\Psi_{\mathrm{W}}=$ Leaf water potential, $* * *$ Significant at $P<1 \%$ level, $* *$ Significant at $P<5 \%$ level, * Significant at $P<10 \%$ level and NS = Non-significant (Values followed by same letter do not differ significantly [Duncan multiple range test $(\alpha \leq 0.05)$ ]). 
effect of $\mathrm{Y} x \mathrm{~L}$ on proline contents revealed the maximum value noted during 2009-10 at Talagang (Fig. 5) while lowest recorded at Islamabad during 2008-09. The significant change from maximum value to minimum value of proline was $50.37 \%$. The box whisker plot further elaborated that proline contents increased significantly with high temperature and low water (Fig. 4) while inverse relationship existed for opposite trait that is at optimum temperature and water, proline contents remained minimum. Proline contents for Y x PW interactive effect depicted significant difference (Fig. 5). The result depicted maximum value during 2009-10 among all PW's as compared to 2008-09. The L x PW interactive effect on leaf proline contents showed that maximum value recorded for PW5 at Talagang while minimum value at Islamabad for PW2 (Fig. 5). The interactive effect of $Y \times$ x revealed that maximum value of proline recorded for Chakwal-50 during 2008-09 which differed significantly from all other interactive values (Fig. 5). Proline contents for L x G interactive effects differed significantly (Fig. 5). The maximum proline contents recorded at Talagang among all genotypes while minimum value noted at Islamabad. The interactive effect of PW $x \mathrm{G}$ on proline contents showed maximum value for PW5 for Chakwal-50.
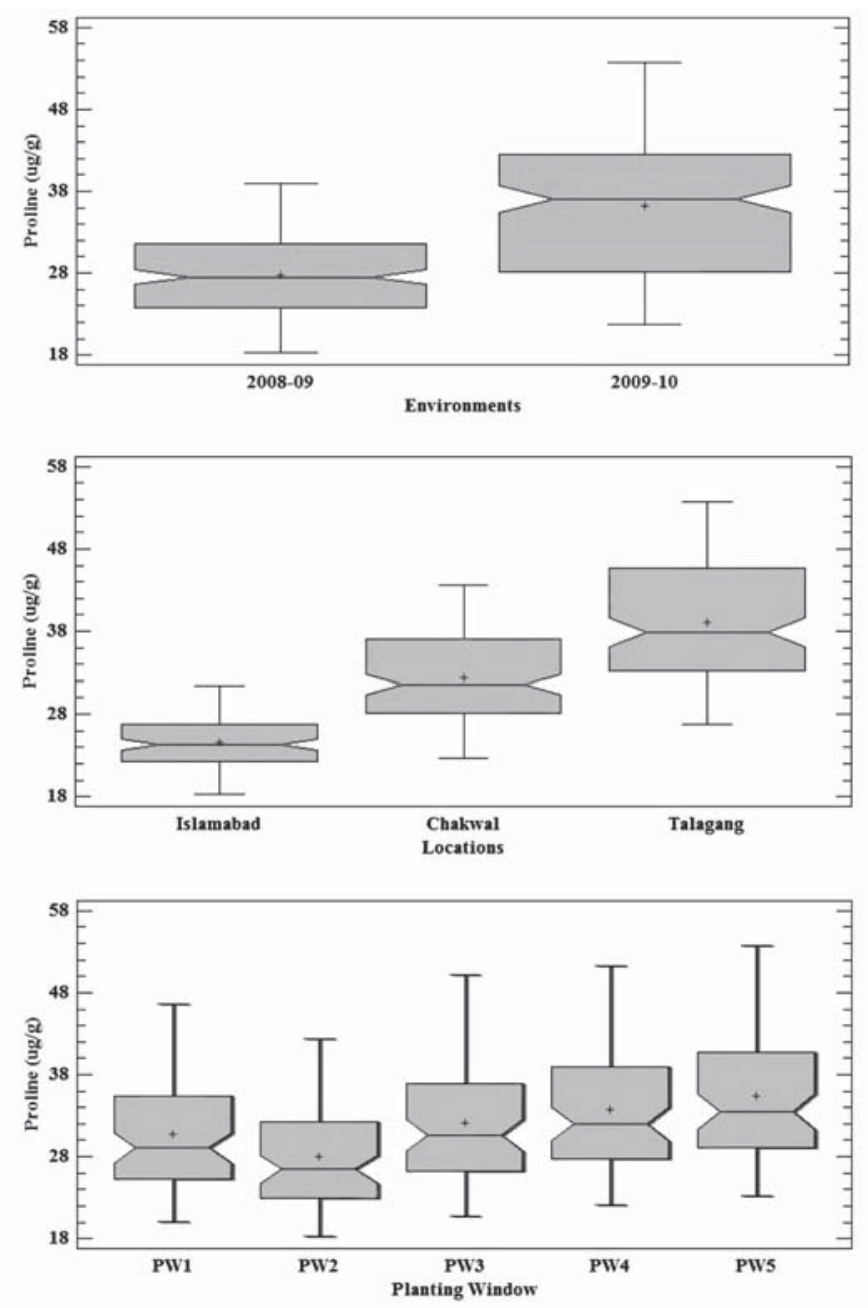

Fig. 3. Box-whisker plot showing the trend of proline content $(\mu \mathrm{g}$ $\mathrm{g}^{-1}$ ) (y axis) during two years, at three locations and for five different planting windows respectively. The middle line of plot is mean while vertical bars represent dispersion from mean.

\subsection{0 grain weight}

Significant difference was observed for thousand grain weight (TGW) among all treatments. The TGW remained highest during 2008-09 while it remained lowest during 2009-10. Among locations the highest TGW was observed at Islamabad while it remained lowest at Talagang (Table 1). The maximum TGW recorded for genotypes Chakwal-50 followed by Wafaq-2001 and GA-2002. Among PW's the TGW remained highest for PW2 followed by PW3 while it remained lowest for PW5 (Table 1).

\subsection{Grain yield}

The wheat plant showed significant variability for grain yield in response to all treatments. The highest grain yield was observed during 2008-09. Among locations the maximum yield obtained at Islamabad followed by Chakwal. The significance of interactive effects on grain yield is shown in Table 1. Similarly, genotypes also depicted significant variability for grain yield (Tables 1 and 2). The interactive effect of Locations (L) $\mathrm{x}$ Genotypes (G) x Managements (PW's) on grain yield showed higher grain yield at Islamabad $\left(4.5 \mathrm{t} \mathrm{ha}^{-1}\right)$ for Wafaq-2001 while minimum yield recorded at Talagang for PW5 $\left(1.0 \mathrm{t} \mathrm{ha}^{-1}\right)$ by same genotype (Table 2). Among management, the highest grain yield was observed for PW2 while it remained lowest for PW5.
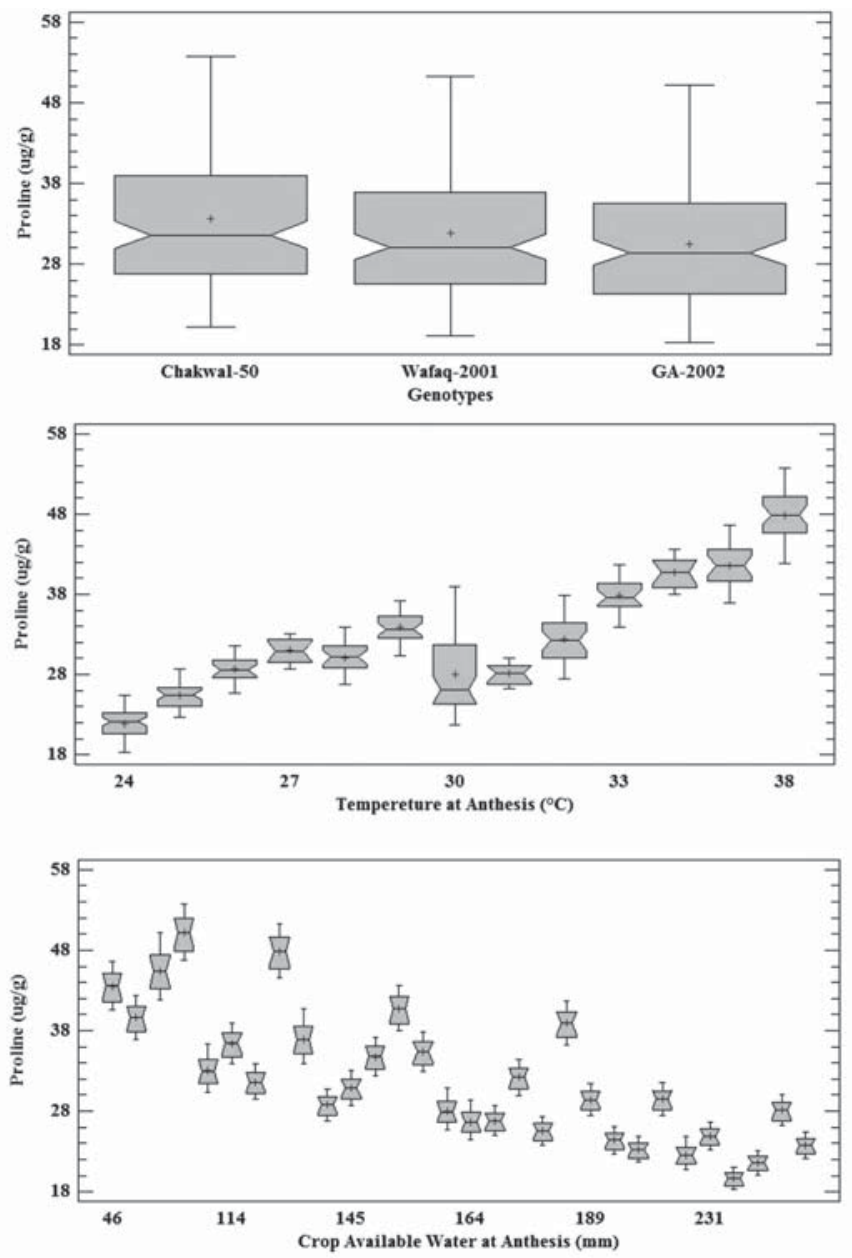

Fig. 4. Box-whisker plot showing the trend of proline content ( $\mu \mathrm{g}$ $\mathrm{g}^{-1}$ ) (y axis) among three genotypes, at anthesis temperature and for crop available water at anthesis respectively. 

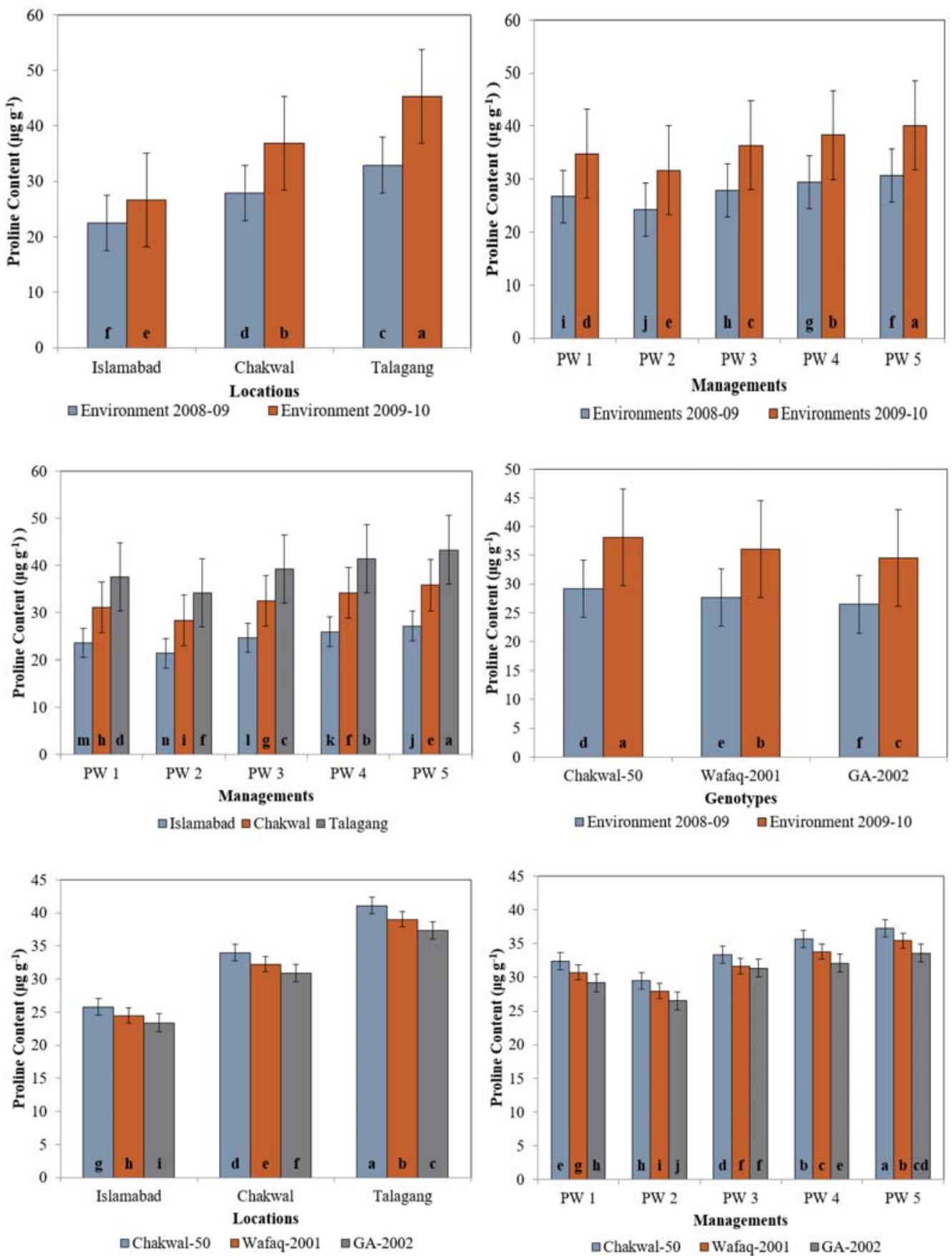

Fig. 5. Concentration of Proline content $\left(\mu \mathrm{g} \mathrm{g}^{-1}\right)$ in response to two way interactions among different treatments (Values followed by same letter do not differ significantly for Proline content $\left(\mu \mathrm{g} \mathrm{g}^{-1}\right)$ in response to different treatments [Duncan multiple range test $(\alpha \leq 0.05)])$.

The results for managements (PW's) depicted maximum grain yield for PW2 $\left(3.1 \mathrm{tha}^{-1}\right)$ and minimum $\left(1.6 \mathrm{tha}^{-1}\right)$ for PW5.

\subsection{Relationship of proline with physiological traits and grain yield}

The proline contents depicted significant relationship with physiological traits and grain yield (Fig. 6). The inverse relationship was observed between stomatal conductance, net photosynthesis, transpiration rate, intercellular $\mathrm{CO}_{2}$, SPAD chlorophyll contents and grain yield. However, proline contents depicted significant positive relationship with stomatal resistance.

\section{Discussion}

Soil water potential remained highest in the field of Chakwal-50 genotypes which might be due to its more time taken to flowering as well as maturity. Similarly, this cultivar has drought tolerant compared to Wafaq-2001 and GA-2002 which resulted to closure of stomata and less requirement of water to complete its life cycle (Mahmood et al., 2013). Proline accumulation in plants under environmental stresses is proteinogenic amino acid with an exceptional conformational rigidity, and is essential for primary metabolism. It acts as a signal to triggers 
Table 2. Grain Yield $\left(\mathrm{t} \mathrm{ha}^{-1}\right)$ of Wheat genotypes under Locations $\mathrm{x}$ Genotypes x Managements interaction.

\begin{tabular}{|c|c|c|c|c|c|c|}
\hline \multirow[b]{2}{*}{ Locations } & \multirow[b]{2}{*}{ Genotypes } & \multicolumn{5}{|c|}{ Managements } \\
\hline & & PW1 & PW2 & PW3 & PW4 & PW5 \\
\hline \multirow{4}{*}{ Islamabad } & Chakwal-50 & $4.1^{\mathrm{ab}}$ & $4.2^{\mathrm{ab}}$ & $2.7^{\mathrm{d}-\mathrm{g}}$ & $2.7^{\mathrm{d}-\mathrm{g}}$ & $2.3^{\mathrm{ghi}}$ \\
\hline & Wafaq-2001 & $3.0^{\mathrm{c}-\mathrm{f}}$ & $4.5^{\mathrm{a}}$ & $2.9^{\mathrm{c}-\mathrm{f}}$ & $3.2^{\mathrm{cd}}$ & $2.6^{\mathrm{d}-\mathrm{g}}$ \\
\hline & GA-2002 & $3.2^{\mathrm{cd}}$ & $3.5^{\mathrm{bc}}$ & $3.2^{\mathrm{cd}}$ & $2.7^{\mathrm{d}-\mathrm{g}}$ & $2.6^{\mathrm{d}-\mathrm{g}}$ \\
\hline & Mean & $3.5^{\mathrm{AB}}$ & $4.1^{\mathrm{A}}$ & $2.9^{\mathrm{BC}}$ & $2.9^{\mathrm{BCD}}$ & $2.5^{\mathrm{CDE}}$ \\
\hline \multirow{4}{*}{ Chakwal } & Chakwal-50 & $2.6^{\mathrm{d}-\mathrm{g}}$ & $3.1^{\mathrm{cd}}$ & $1.9^{\mathrm{h}-\mathrm{m}}$ & $1.2^{1-0}$ & $1.3^{1-0}$ \\
\hline & Wafaq-2001 & $2.1^{\mathrm{g}-\mathrm{k}}$ & $3.0^{\text {cde }}$ & $1.3^{1-0}$ & $1.5^{\mathrm{j}-\mathrm{o}}$ & $1.2^{\mathrm{mno}}$ \\
\hline & GA-2002 & $2.1^{\mathrm{g}-\mathrm{k}}$ & $2.4^{\mathrm{e}-\mathrm{i}}$ & $1.8^{\mathrm{h}-\mathrm{m}}$ & $1.4^{\mathrm{k}-\mathrm{o}}$ & $1.4^{\mathrm{k}-\mathrm{o}}$ \\
\hline & Mean & $2.2^{\mathrm{DEF}}$ & $2.8^{\mathrm{BCD}}$ & $1.6^{\mathrm{FGH}}$ & $1.3^{\mathrm{GH}}$ & $1.3^{\mathrm{GH}}$ \\
\hline \multirow{4}{*}{ Talagang } & Chakwal-50 & $2.2^{\mathrm{g}-\mathrm{j}}$ & $2.3^{\mathrm{f}-\mathrm{i}}$ & $1.7^{\mathrm{h}-\mathrm{n}}$ & $1.1^{\mathrm{no}}$ & $1.0^{\mathrm{no}}$ \\
\hline & Wafaq-2001 & $1.5^{\mathrm{j}-\mathrm{o}}$ & $2.4^{\mathrm{e}-\mathrm{h}}$ & $1.2^{1-\mathrm{o}}$ & $1.4^{1-0}$ & $1.0^{\circ}$ \\
\hline & GA-2002 & $1.9^{\mathrm{h}-1}$ & $2.6^{\mathrm{d}-\mathrm{g}}$ & $1.6^{\mathrm{i}-\mathrm{o}}$ & $1.2^{1-\mathrm{o}}$ & $1.2^{1-0}$ \\
\hline & Mean & $1.8^{\mathrm{EFG}}$ & $2.4^{\mathrm{CDE}}$ & $1.5^{\mathrm{GH}}$ & $1.2^{\mathrm{GH}}$ & $1.1^{\mathrm{H}}$ \\
\hline
\end{tabular}

(Common letter means does not differ significantly at $P<5 \%$ ).

specific gene action which is essential for crop recovery from stress (Yue et al., 2006). The higher value during 2009-10 might be due to water and temperature stresses prevailed during growing season of crop (Figs. 2 and 3). Similar findings about accumulation of proline under environmental stresses were reported by Li et al. (2005). The increased accumulation of proline under environmental stresses were reported by earlier researcher who concluded that proline helps to stabilize membranes and other proteins (sub-cellular structures), maintains cellular redox potential by buffering actions and destroy free radicals (Ozturk and Demir, 2002 and Kavi Kishore et al., 2005). As in our studies proline accumulation resulted to the maintenance of leaf water potential which resulted to the optimum yield even under stress conditions (Table 1).

The higher production of proline during 2009-10 might be considered as drought resistance mechanism of crop to maintain wheat crop physiological traits and yield so that crop may survive under stress conditions. Similarly, production of antioxidants and osmotic adjustment has significant relationship with accumulation of proline in wheat crop. Therefore, proline could build drought tolerance in crops (Yue et al., 2006). Yang et al. (2005) reported a strong correlation with proline and stress tolerance. In their study they concluded that accumulation and synthesis of proline resulted to higher crop growth under severe water stress. Similarly, highest proline value at Talagnag may have been due to environmental stresses like temperature and water whereas favourable environmental conditions of Islamabad did not favour proline synthesis. Therefore, in present study drought stress increased proline contents significantly (Li et al., 2005).

The maximum value of proline in Chakwal-50 may be due to its resistance mechanism toward stress which resulted to the highest leaf water potential. Present study proved that proline acts as protective in crops against abiotic stress (Verbruggen and Hermans, 2008). The accumulation of free proline and sugars in plants under stress like drought and high temperature are defensive mechanism of plants to survive under harsh conditions by maintaining turgidity of cell (Quan et al., 2004). The results obtained in this study revealed that abiotic stress like high temperature and drought resulted in an increase in proline in all genotypes but this increase was more pronounced in Chakwal-50. The higher level of proline in this genotype might be described as its improved drought resistance under environmental stresses. The role of proline in enhancing plant tolerance has been proved in our findings. It could be concluded that proline helped in adaptation of wheat crop to high temperature and drought tolerance by either stabilizing the structure of complex proteins or by marinating the integrity of membranes. The results further elaborated that water and heat stress caused the synthesis and accumulation of all active compounds in resistant wheat genotypes compared to non-resistant one which maintains the TGW and grain yield (Table 1).

The maximum value of proline recorded for PW5 $\left(35.42 \mu \mathrm{g} \mathrm{g}^{-1}\right)$ and it was due to exposure of crop to environmental stresses due to late sowing. Since if crop is sown late it exposed to low temperature at earlier growth stages while higher temperature at later stages which resulted to increment of proline contents in crop (Fig. 4). Similarly, moisture stress also affected the crop at later stages as depicted by soil water potential (Table 1). The lowest value of proline contents $\left(27.97 \mu \mathrm{g} \mathrm{g}^{-1}\right)$ was recorded for PW2. The response of crops toward environmental stresses might be quantified by calculating amount of proline accumulated which was used to improve stress tolerance in crops. Ma et al. (2006) concluded that foliar application of proline under stress years resulted to drought tolerance and optimum physiological traits in wheat (Fig. 6).

The highest value at Talagang during 2009-10 was due to environmental stresses like tempearture and water. The highest accumulation of proline at Talagang sepecifically during 200910 might be due to stress conditions. The box-whisker plot further ealobrated that proline contents increased signifcantly with high tempearture (Fig. 4) while inverse relationship existed for opossite. The proline metabolism and its accumulation are an imporatnt process to build up tolerance in crops under adverse environmetal conditions (Khan et al., 2009). Similarly, response of crop to multiple stresses is different from signle one therfore, proline production as protectant colud be considered as indicator of defensive mechansim of crop in response to multiple stresses. The maximum value in second environment may be due to adverse environmental conditions. Frances et al. (2006) concluded that accumulation of proline increased under stress and it optimized the grain yield by maintaining leaf water potential (Table 1). In present studies heat and water stress stimulated proline/ osmoprotectant concentration significantly (Raza et al., 2007). Khan et al. (2009) concluded that under stress proline contents increased significantly which helps in the mainteance of physiological traits and grain yield. Therfore, survival of crops under stress is possible by proline accumulation and maintenace of leaf water potential to optimum level (Table 1). Wang et al. (2010) and Khan et al. (2009) reported inacresed proline concentration under stress conditions in resistance genotypes. Frances et al. (2006) concluded that drought tolerance in crops is only possible by the synthesis and accumulation of proline. Therefore, 

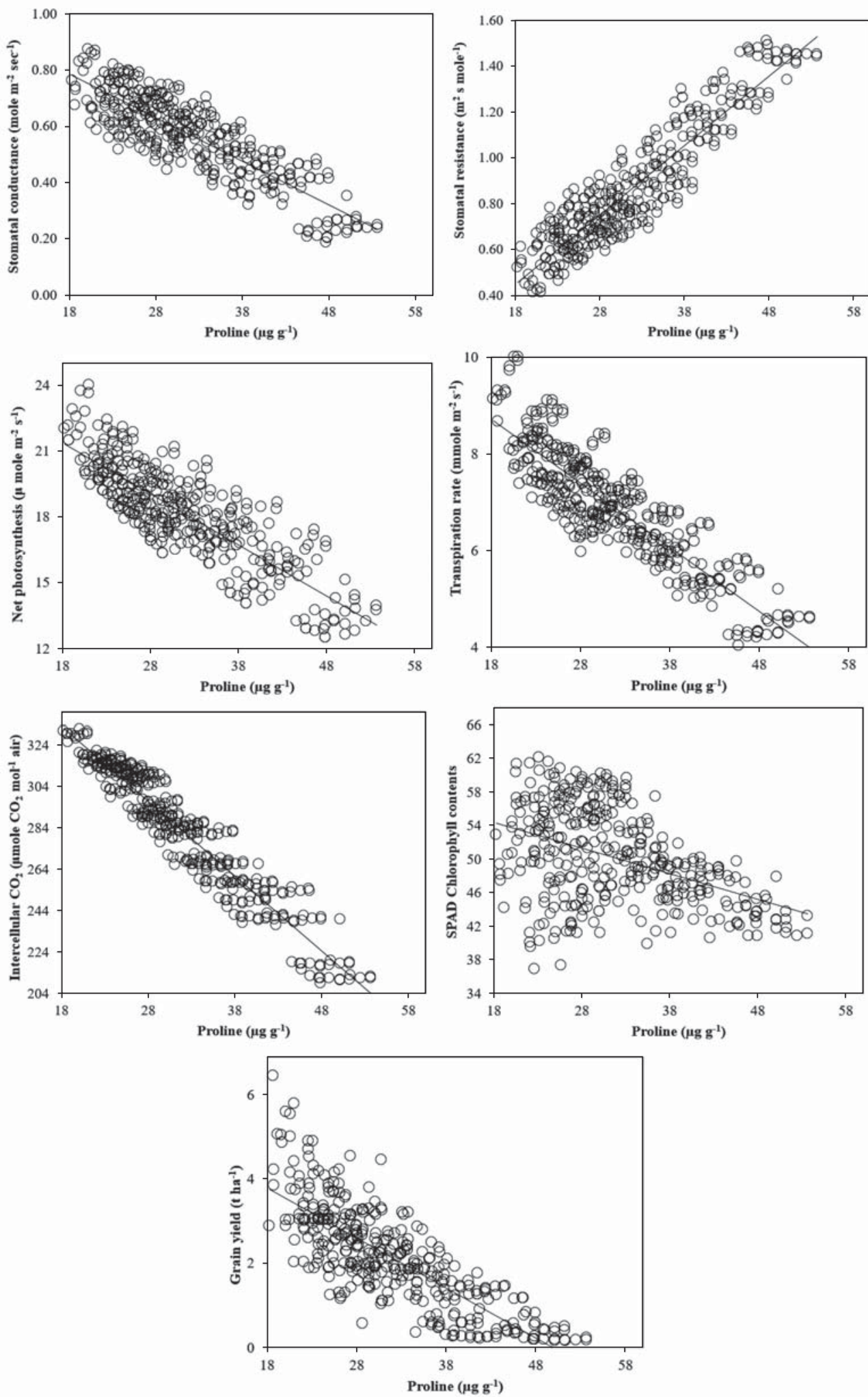

Fig. 6. Relationship of proline with physiological traits and grain yield combined over years, locations, planting windows and genotypes $(n=360)$.

proline could be considered as good osmoprotectant under abiotic stresses and it could be potentially used artificially to uplift stress under rainfed conditions. Similarly, genotypes which have higher accumulation of proline but without the expense of physiological and grain yield traits should be considered for breeding programmes.

\section{Conclusions}

A significant increases in the concentration of proline as osmoprotectant was recorded in wheat under abiotic stresses like high temperature and water which resulted to the optimization of TGW and grain yield. However, among genotypes the highest 
proline was recorded for Chakwal-50 which resulted to the maintenance of leaf water potential and grain yield. The proline accumulation further helps in the completion of crop life cycle by mitigating abiotic stresses. The synthesis of proline appeared to be strongly linked with resistant varieties than non-resistant one. Similarly, metabolic synthesis of proline has strong coordination with abiotic stresses like high temperature and low water. Thus, breeding and recommendations of genotypes like Chakwal-50 having physiological and morphological synchronization with abiotic stresses need to be recommended. Meanwhile adaptation of proper sowing time according to changing climate needs to be opted for sustainable wheat yield production.

\section{Acknowledgements}

We wish to thank the Higher Education Commission of Pakistan for the financial support provided, and anonymous reviewers for their constructive comments.

\section{References}

Ashraf M, Foolad MR, 2007: Roles of glycine betaine and proline in improving plant abiotic stress resistance. Environmental Experimental Botany 59, 206-216.

Aziz I, Khan MA, 2001: Experimental assessment of salinity tolerance of Ceriops tagal seedlings and saplings from the Indus Delta, Pakistan. Aquatic Botany 70, 259-268.

Bohnert HJ, Jensen RG, 1996: Strategies for engineering water-stress tolerance in plants. Trends in Biotechnology 14, 89-97.

Dore MHI, 2005: Climate change and changes in global precipitation patterns: What do we know? Environment International 31, 1167-1181.

Easterling DR, Meehl GA, Parmesan C, Changnon SA, Karl TR, Mearns LO, 2000: Climate extremes: Observations, modeling, and impacts. Science 289, 2068-2074.

Foolad MR, Lin GY, 2001: Genetic analysis of cold tolerance during vegetative growth in tomato, Lycopersicon esculentum Mill. Euphytica 122, 105-111.

Frances MD, William JH, William HV, Charlene T, Kerry MK, Okkyung KC, Susan BA, 2006: Protein accumulation and composition in wheat grains: effects of mineral nutrients and high temperature. European Journal of Agronomy 25, 96-107.

Hubbell SP, 2001: The Unified Neutral Theory of Biodiversity and Biogeography (MPB-32). Princeton University Press. Princeton, New Jersey.

Hughes L, 2003: Climate change and Australia: Trends, projections and impacts. Austral Ecology 28, 423-443.

Kavi Kishore PB, Sangam S, Amrutha RN, Laxmi PS, Naidu KR, Rao KRSS, Rao S, Reddy KJ, Theriappan P, Sreenivasulu N, 2005: Regulation of proline biosynthesis, degradation, uptake and transport in higher plants: its implications in plant growth and abiotic stress tolerance. Current Science $\mathbf{8 8}$, 424-438.

Khan MS, Yu X, Kikuchi A, Asahina M, 2009: Genetic engineering of glycine betaine biosynthesis to enhance abiotic stress tolerance in plants. Plant Biotechnology 26, 125-134.

Li Y, Wang W, Yang X, Zou Q, 2005: Expression of BADH and betaine content in wheat cultivars with different drought resistance under drought stress. Acta Agronomica Sinica. 31, 425-430.

Ma QQ, Wang W, Li YH, Li DQ, Zou Q, 2006: Alleviation of photoinhibition in drought-stressed wheat (Triticum aestivum) by foliar-applied glycinebetaine. Journal of Plant Physiology 163, 165-175.

Mahmood A, Mian MA, Ihsan M, Ijaz MG, Iqbal MS, 2013: Chakwal-50: A high yielding and disease resistant wheat variety for rainfed region. The Journal of Animal and Plant Sciences 23, 833-839.

Ozturk L, Demir Y, 2002: In vivo and in vitro protective role of proline. Plant Growth Regulation 38, 259-264.

Quan RD, Shang M, Zhang H, Zhao YX, Zhang JR, 2004: Improved chilling tolerance by transformation with beta gene for the enhancement of glycinebetaine synthesis in maize. Plant Science 166, 141-149.

Raza SH, Athar HR, Ashraf M, Hameed A, 2007: Glycinebetaine-induced modulation of antioxidant enzymes activities and ion accumulation in two wheat cultivars differing in salt tolerance. Environnemental and Experimental Botany 60, 368-376.

Rontein D, Basset G, Hanson AD, 2002: Metabolic engineering of osmo-protectant accumulation in plants. Metabolic Engineering 4, 49-56.

Sivakumar MVK, Das HP, Brunini O, 2005: Impacts of present and future climate variability and change on agriculture and forestry in the arid and semi-arid tropics. Climatic Change $\mathbf{7 0}$, $31-72$.

Verbruggen N, Hermans C, 2008: Proline accumulation in plants: a review. Amino Acids 35, 753-759.

Wang GP, Li F, Zhang J, Zhao MR, Hui Z, Wang W, 2010: Overaccumulation of glycine betaine enhances tolerance of the photosynthetic apparatus to drought and heat stress in wheat. Photosynthetica 48, 30-41.

Yang X, Liang Z, Lu C, 2005: Genetic engineering of the biosynthesis of glycinebetaine enhances photosynthesis against high temperature stress in transgenic tobacco plants. Plant Physiology 138, 2299-2309.

Yue B, Xue W, Xiong L, Yu X, Luo L, Cui K, Jin D, Xing Y, Zhang Q, 2006: Genetic basis of drought resistance at reproductive stage in rice, separation of drought tolerance from drought avoidance. Genetics 172, 1213-1228.

Zhu JK, 2002: Salt and drought stress signal transduction in plants. Annual Review of Plant Biology 53, 247-273. 